\title{
Activation of Innovative Development in the Conditions of the DEST World
}

\author{
MARIIA TEPLIUK \\ Department of Business Economics and Entrepreneurship, \\ State higher educational establishment, \\ Kyiv National Economic University named after Vadym Hetman, Ukraine
}

\section{OLEXANDR SHAPRAN}

Corporate Finance and Controlling Department, State higher educational establishment, Kyiv National Economic University named after Vadym Hetman

\begin{abstract}
The article proves that at the present time when countries are joining forces to recover, prosper and overcome the global economic and financial crisis associated with COVID-19, scientists and practitioners are focusing on updating the development of innovative entrepreneurship. It will lead to economic recovery, job creation, and in the long run, it will lead to a reduction in poverty. It will lead to the solution of crucial social problems. Ensuring the increase in sufficient activity of economic entities in presentday conditions of operation requires a timely review of the needs of the external and internal environment and the search for ways to meet them. The purpose of the article
\end{abstract}


is to identify the key parameters of the activation of innovative development in the context of the DEST World

Keywords: innovative, innovative development, DEST World, COVID-19

JEL Classification Code: M12

\section{Introduction}

Today, the world is experiencing a decline in stock indices, the flight of investors from developing countries, declining demand in world commodity markets, a record decline in the Dow Jones industrial average, oil wars. Besides, the World Health Organization (WHO) has announced that the COVID-19 virus has reached a pandemic scale - most countries have pledged to implement restrictive measures to prevent the spread of the disease. To intensify the innovative development of the enterprise, an essential condition for maintaining its market position and scaling in the future is meeting the needs of external customers, and internally - management at various levels, owners, shareholders, and other stakeholders. Undoubtedly, in a changing environment, companies need to innovate, exclusively, as noted by S. Jobs and M. Dell, that it is vital to question the stability of the foundation of a successful organisation, carrying out innovative changes in the lifecycle, and even if the company is at the peak of popularity. Social media, the Internet of Things, digital products, sensors as a service, integration of virtual and physical reality, Big Data, etc. - on the one hand, the current causes of dynamic changes in business conditions in which market players operate, on the other - the consequences of their activities. These business trends, generated by information technology (IT), increase the level of relevance of their use not only today but also in the long run (Ua-advice, 2020).

\section{Peculiarities of activating innovative development in the context of the DESTWorld}

The rapid spread of the COVID-19 pandemic in early 2020 involves the use of corporate social responsibility (CSR) by businesses as an exclusive form of doing business. The common goal of most companies is to find ways to reduce the negative impact of pandemic measures on their activities (according to experts, business losses in one quarter in Ukraine, due to restrictive measures, will amount to about UAH 20 billion) (Economic Truth, 2020). It is possible only through internal changes and external synergies. 
Consider the behavioural mechanism of the enterprise's response to external barriers through the biological concept of the enterprise. To do this, the Kubler-Ross model should be used, which describes the 5 Stages of Death (Corr, 2020). These stages were identified as defense mechanisms or coping mechanisms with change, loss, and/ or shock. The stages were not meant to be described as linear, nor in a step-by-step manner. However, for the sake of written description, they have been laid out in the now famous DABDA (Denial, Anger, Bargaining, Depression, Acceptance) manner as it is a common path taken (Ua-advice, 2020). Kubler-Ross's legacy has found its place in corporate governance: large companies from Boeing to IBM (including the $\mathrm{BBC}$ ) have used the change curve developed to help employees in times of major business change. And during a pandemic it can be used, says psychologist David Kessler (Kessler, 2019).

Thus, we should pay attention to the adaptation of enterprises to the conditions of their operation, which is not linear and is determined on the one hand by internal and external consumers, as well as decisions of governing bodies, and on the other - the external environment.

As a result, the service sector suffers compelling costs, in particular, in terms of (Economic Truth, 2020):

- logistics (international and domestic passenger traffic) - the UIA expects revenue loss of about $35 \%$ a quarter;

- catering establishments - sales of public catering establishments in Ukraine decreased by an average of $35 \%$. Experts estimate that the restaurant business will lose up to $50 \%$, including the dismissal of a lot of staff;

- the entertainment sector (cinemas, entertainment centres, etc.) - according to a study of the Multiplex cinema network in Ukraine, the losses of the sector will reach about UAH 80 million per month;

- the purchasing power of the event industry fell by about $70 \%$ due to the high uncertainty of concerts, performances, forums;

- shopping centres and shops - losses for the quarantine period are estimated at a minimum of UAH 250-300 million. For example, Gulliver Mall has reduced the number of cleaning staff at the facility by 2.5 times;

- tourist services - losses for the tourism industry in Ukraine will reach 3-5 billion dollars. At the same time, approximately $80 \%$ of hospitality establishments are small businesses, as well as sole proprietors;

- the banking sector - most banks suspended their branches (Alfa-Bank suspended 45 branches across the country), stopped cash exchange at cash desks (Privatbank, Alfa-Bank, etc.), the overwhelming majority took advantage of the support of the NBU system (national) banks (Ukrinform, 2020); 
- the church - in Germany the church introduced psalms in the mobile application, sermons in social networks, etc.

Therefore, the most devastating consequences are for entertainment and cultural institutions, hotel and restaurant businesses, tour operators and agencies, business in the field of cosmetology services, as well as business in the areas of passenger transportation, insurance, advertising, construction, and private educational institutions.

Despite the severe limitations and functioning of enterprises in the DEST world (Disorder - full of unexpected changes; Egocentrism - focused on personal interests and goals; Suppression - refusal to disclose or publish; Turbulence - manifested through conflict, confusion, over which there is no control - unlike the VUCA world, where ther is focus on goals).

Particular attention should be paid to opportunities for existing businesses and start-ups in the market - finding ways to turn external threats and weaknesses into strengths, taking into account current trends and interaction with external parties; formation of dynamic abilities (distinctive competencies) and proactive behaviour that provide prolonged competitive advantages (BBC, 2020).

To illustrate the above-mentioned facts, we will use the tools of trendwatching and benchmarking, as presented in Figure 1.

Figure 1. Crisis management matrix

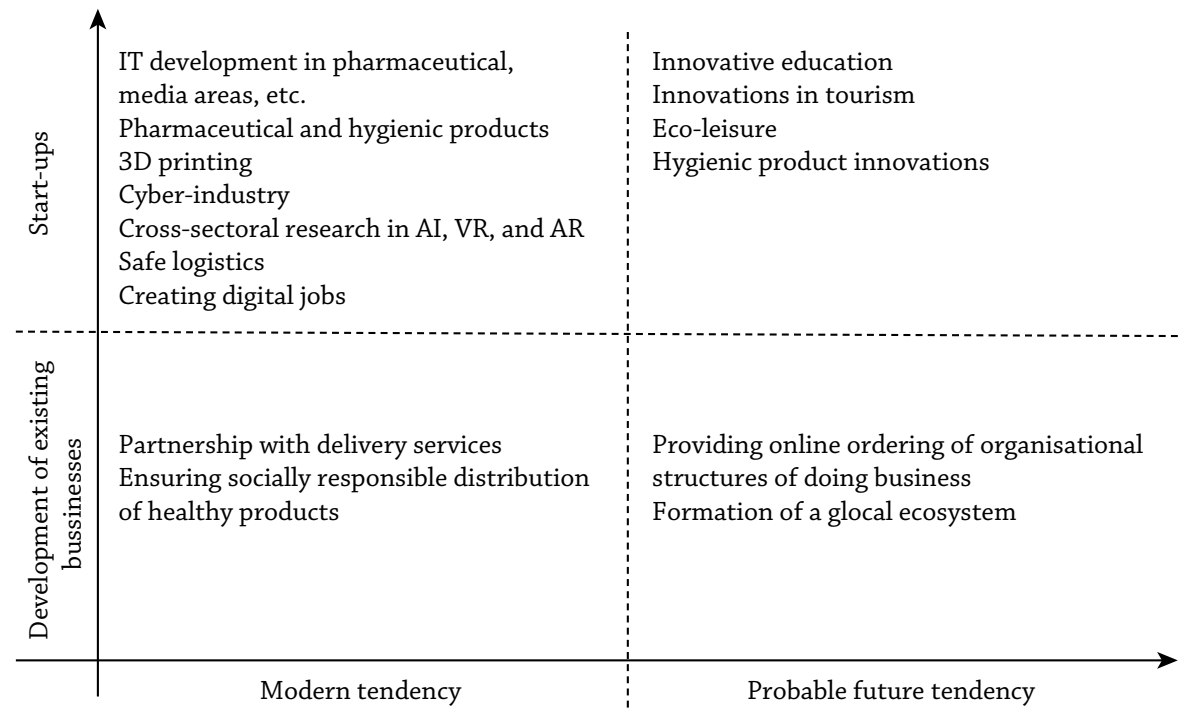

Source: own work. 
The crisis situation present today is determined, first of all, by the large information field, which we will consider through the prism of two aspects:

- the lack of user trust in the media;

- the system of filtering information by social networks is not established.

What does this mean for business? Opportunities - for start-ups in the context of globalisation and Industry 4.0, it is the development of software, artificial intelligence, virtual and augmented reality (Glavcom, 2020). The implementation of this principle is currently being actively performed by start-ups in the field of medicine through 3D printing, in particular Isinnova, which has developed a batch of valves (it allows them to produce 100 pieces per day) for artificial ventilation systems (Tepliuk et al., 2020)

The Vocalis Health startup is currently researching to identify a voice imprint unique to those who have a respiratory virus to help the Department of Health identify infections better. If start-ups are launching new products, what actions are in place for existing market players in the current situation? Analytical research shows that the introduction of quarantine has led to a massive transition of employers to remote work and study. Bloomberg notes that in recent days, the share price of Zoom has risen by $40 \%$. According to a study by Sensor Tower, recent downloads of the application have increased by $109 \%$ (Somanas, 2020).

Besides, retail research shows that $41 \%$ of the respondents in cities in Ukraine with a population of 50,000 or more say they have experience of ordering food online. The companies like Uber Eats, Glovo, Raketa in the conditions of quarantine observe an increase in demand for services to $70 \%$ (Kabachynskyi, 2020). Menu.ua for the day after the announcement of quarantine received an increase in orders up to $25 \%$. The growth of online sales has particularly affected European countries, including France $-187 \%$, Italy $-182 \%$, Spain -162\%, Australia -145\%. For example, Chinese online retailer Miss Fresh claims that the older age group of users increased by $237 \%$ as a result of the pandemic, and the Internet giant Alibaba recorded a fourfold increase in sales in this segment.

For a start-up and existing business, the beginning (expansion) of activity in a crisis has several advantages, we characterise the key ones:

1) the unemployment rate increases during the crisis - a high probability of attracting highly skilled workers at average market wages (which are low during the crisis);

2) the cost of materials, raw materials and equipment during the crisis decreases. However, if purchases from abroad are envisaged, the opposite effect is observed, as the Ukrainian hryvnia depreciates significantly during crises (only from March by $15 \%$ against the dollar);

3) reduced competition - the crisis pushes many players out of the market, and therefore, there is wider access to customers (Boichenko et al., 2019). 
So, companies in the market need:

- firstly, to adapt to operating conditions, even through the use of diversification or differentiation strategies and to find partners. A clear example is Bosch, which introduced a new test for the coronavirus, which takes only 2.5 hours. An important difference is the lack of need to send it to special laboratories. Introduced by RADLogics software based on artificial intelligence, which forms a quantitative coronavirus index - allows one to measure the dynamics of the disease over time;

- secondly, to take social responsibility of business based on interaction with all stakeholders following the ethical norms of society. Social responsibility programmes should be a mandatory element of any company focused on successful activities, and the use of basic principles of CSR will provide it not only with a positive perception in society but also a high level of self-development of its employees, a harmonious combination of business interests (including profit) with the social needs of society. For example, WOG has joined the initiative of the Ministry of Health and will provide free fuel for ambulances during quarantine, and Nova Poshta will hire 2,000 couriers and deliver aid to hospitals and the military free of charge (Tepliuk et al., 2020);

- thirdly, to create their own rules of the game, setting development models for other players - based on the above areas, companies should not only adapt to business conditions but use socially responsible activities to encourage other players to form an eco-space based on the knowledge triangle.

Attention should be focused on the right side of the matrix, namely, on the use of probabilistic future trends as a source of meeting consumer needs in the future and achieving sustainable competitive advantages. Thus, proactive behaviour should underlie the company's activities at the stage of its inception and be maintained throughout the life cycle of the enterprise (the vast majority of such companies are created in the form of start-ups), especially in crisis conditions (Boichenko et al., 2019). Schematically proactive behaviour can be depicted as follows, see Figure 2 below.

In particular, thanks to the proposed triad it is possible to trace: at the entrance - resource provision; the process of initiation and implementation of innovations based on the well-established organisation of interaction within the enterprise of personnel and management, as well as externally - the enterprise and its customers. Organisations from the perspective of corporate entrepreneurship implementation will have the effect of increasing the efficiency of activities within the enterprise, as well as the growth of external indicators of the enterprise in the market.

According to the leading Italian psychoanalyst and philosopher, S. Benvenuto, the consequences of the pandemic will intensify the trend for which smart work, work from home avoiding commuting to the office, is only one aspect. In modern conditions, this view is gaining popularity, especially among supporters of the theory 
of generations created by American scientists N. Howe and W. Strauss in 1991 (Howe \& Strauss, 1991). Today, the gradual growth of direct and indirect consumption of digital products (services) by generations $\mathrm{Y}$ and $\mathrm{Z}$ prevails.

Figure 2. The triad of proactive behaviour of the company

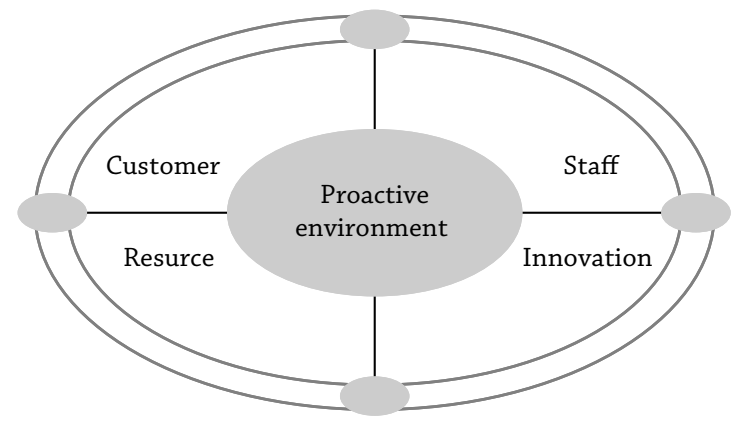

Source: own work based on Tepliuk et al. (2020).

Soon, experts predict the emergence of new ways to meet existing needs:

1) being online anywhere in the world;

2) receiving online education with the use of $\mathrm{VR}$ or $\mathrm{AR}$ - it is assumed to be better training than offline education;

3) viewing online theatrical productions, films with personalised content for everyone;

4) training online at home with the best athletes and cyber players;

5) shopping and fitting clothes, shoes, etc., on a digital duplicate and the likes.

Besides, it is expected that a significant proportion of the population will strengthen training in hygiene and public appearances. Thus, special attention is paid to understanding the need to create favourable living conditions for all, because clean water, hygiene products and medicines - resources - are limited and still not available to everyone on the planet.

According to pessimistic forecasts, 1 billion new users will move to online services. Obviously, the outflow of offline users is expected, but at the same time, after assessing the possibilities, the use of digital services will continue.

\section{Conclusion and future research}

Today, digitalisation processes cover most areas of human activity, especially smart houses, sensors, drones, robotics, the use of which is primarily related to the safety of health, life, property, and the future. Thus, in the era of change, companies need to be ready to work in conditions of high uncertainty, which means 
rapid decision-making, responses to changing working conditions, allocation and redistribution of resources, time management in the flow of work tasks; start-ups should take into account external conditions and trend opportunities to obtain long-term benefits in the future. The implementation of this approach is possible by taking into account proactive behaviour based on the interaction of suppliers, staff, and customers. The latter, in turn, according to the theory of generations and environmental constraints, tend to take advantage of Industry 4.0, which, on the one hand, is determined by technological changes, and on the other, by globalisation.

\section{References}

BBC (2020). Coronavirus: Italian startup has created a valve for ventilators on a 3D printer. Retrieved from: https://www.bbc.com/russian/news-51951533 (accessed: 15.2.2021).

Boichenko, K.S., Tepliuk, M.A., Rekova, N. Yu., Stashkevych, I.I., \& Morkunas, M. (2019). Management of Fluctuation of Financial and Economic Integrated Development of Innovative Enterprise. Financial and credit activity: problems of theory and practice, 3(30), 62-69.

Corr, C.A. (2020, Dec). Elisabeth Kübler-Ross and the «Five Stages» Model in a Sampling of Recent American Textbooks. Omega (Westport), 82(2), 294-322.

Day (2020). Shares of Zoom video conferencing service have doubled since the beginning of the epidemic. Retrieved from: https://day.kyiv.ua/uk/news/250320-akciyi-servisuvideokonferenciy-zoom-zrosly-vdvichi-vid-pochatku-epidemiyi-covid-19 (accessed: 10.2.2021).

Economic Truth (2020). Chronicles of the business crisis: who in Ukraine will be mostly covered by the storm of coronavirus. Retrieved from: https://www.althoughda.com. ua/publications/2020/03/19/658296/ (accessed: 11.2.2021).

Glavcom (2020). German Bosch presented a test for coronavirus. Retrieved from: https:// glavcom.ua/techno/hitech/nimci-vinayshli-shvidkiy-test-na-koronavirus-669004. html (accessed: 15.2.2021).

GU SES of Ukraine (2020). Who do you want to be during the COVID-19 pandemic? Retrieved from: https://dp.dsns.gov.ua/ua/Ostanni-novini/24501.html (accessed: 15.2.2021).

Howe, N., \& Strauss, W. (1991). Generations: The history of America's. future, 1584 to 2069. New. York: William Morrow and Co.

Kabachynskyi, I. (2020). How and why Uber Eats shut down in Ukraine: "Employees have been laid off without warning". Retrieved from: https://ain.ua/en/2020/05/08/howand-why-uber-eats-shut-down-in-ukraine/ (accessed: 15.2.2021).

Ries, A., \& Trout, J. (1982). Positioning: The Battle for Your Mind. Maidenhead: McGraw Hill. Somanas, A. (2020). 10 business sectors boosted by coronavirus concerns. Retrieved from: https://www.fm-magazine.com/news/2020/apr/business-sectors-boosted-bycoronavirus-concerns.html (accessed: 15.2.2021). 
Stepankovska, J. (2018). Change or die. Fifty professions will disappear by 2030. Retrieved from: https://glavcom.ua/publications/zminyuysya-abo-pomri-do-2030-roku-zniknepivsotni-profesiy-natomist-zyavlyatsya-186-novih-520807.html (accessed: 15.2.2021).

Ua-advice (2020). Business crisis in Ukraine 2020: who will be affected by the coronavirus worse. Retrieved from: https://ua-advice.com/kriza-biznesu-v-ukra-ni-dlya-kogokoronavirus-vpline-girshe/ (accessed: 15.2.2021).

Ukrinform (2020). Churches - on the Internet, confession - by phone. Retrieved from: https://www.ukrinform.ua/rubric-world/2902816-cerkvi-v-interneti-spovidtelefonom.html (accessed: 15.2.2021).

Tepliuk, M.A., Liezina, A.V., Zavyalova, M.V., Lysenko, N.S., \& Yavorska, A.F. (2020). Valuable aspects in the enterprise management process. Financial and credit activity: problems of theory and practice, 1(32), 206-212.

\section{Acknowledgements}

The publication is prepared under the scientific project Realization of the young scientists' potential in integration of science, education, and business (Ukrainian state registration number 0120U102126).

\section{Tepliuk Mariia}

PhDin Economics, Associate Professor of Business Economics and Entrepreneurship, SHEE KNEU named after. V. Hetman, Ukraine. Her scientific work focuses on the topics of competences, employees' attitudes, organisational behaviour, human capital management and development, person-organisation fit, leadership and innovative development in the conditions of the DEST World.

e-mail address maria_6.11@kneu.edu.ua

ORCID ID: 0000-0001-6823-336X

\section{Shapran Olexandr}

Audit assistant of Deloitte, Ukraine; his scientific work focuses on the topics of competences, employees' attitudes, organisational behaviour, human capital management and development, person-organisation fit, leadership, and innovative development in the conditions of the DEST World.

e-mail: sasha.shapran@gmail.com

ORCID ID: 0000-0003-1663-5062 